\title{
(1) \\ Participatory Approaches and Conservation of Medicinal Plants: Identifying priority species in the community of Areais da Ribanceira (Brazil)
}

\author{
Sofia Zank, Natalia Hanazaki, and Anderson Santos de Mello
}

\section{Research}

\begin{abstract}
Using a participatory approach, we aimed to identify medicinal conservation priority plant species in a region where a sustainable conservation area is being proposed. Local farmers consensually selected 10 ethno-species represented by 11 scientific species (Calea uniflora Less., Equisetum giganteum L., Aristolochia triangularis Cham., Zollernia ilicifolia (Brongn.) Vogel, Maytenus ilicifolia Mart. ex Reissek, Stachytarpheta cayennensis (Rich.) Vahl, Mikania laevigata Sch.Bip. ex Baker, Achyrocline satureioides (Lam.) DC., Lepidium didymum L., Dioscorea altissima Lam., and Picrasma crenata Engl. in Engl. \& Prantl), which were the focus of two participatory tools: four-cell analysis and matrix of plants and environments. Most plants were classified as having high environmental availability and as being under intense extraction pressure. Both natural areas (restinga and hillside forest) and cultivated areas (croplands and homegardens) are important for the acquisition of native medicinal plants. This participatory process tends to facilitate the incorporation of research results by the community, according to its local demands, as well as allowing for a collective learning experience. The use of a participatory approach also allowed the gradual increase in the awareness of the community related to their medicinal plants, contributing to their own decisions about the management and conservation of these resources.
\end{abstract}

\section{Introduction}

Incorporation of traditional knowledge and involvement of local communities on in-situ biodiversity conservation strategies have been advancing significantly. Local development and research participatory methodologies are fundamental in this process (De Boef \& Thijssen 2007, Gaventa \& Cornwall 2006). Participatory approaches, ini- tially employed mainly by NGOs and government agencies, have been also expanded to the sphere of conservation and biodiversity resources research (Chambers 1994). These approaches can be seen as research and development tools, with the aim of incorporating local knowledge and perspectives into resource management, as well as empowering people for greater autonomy in the use and conservation of their own natural resources (De Boef \& Thijssen 2007). Empowerment can be defined as a process that assists individuals or groups of people to acquire control over their own lives, enhancing their capacity to deal with significant subjects, according to their understandings (Eyben et al. 2008).

Participatory methodologies have also been incorporated into ethnobotanical studies (Alexiades 2003, Sieber et al. 2014). Ethnobotany is a transdisciplinary field, which aims to document, describe, and explain complex relations between people and plants (Alcorn 1995), and which has collaborated to a more integrative perspective

\section{Correspondence}

Sofia Zank, Program in Ecology, and Laboratory of Human Ecology and Ethnobotany, Department of Ecology and Zoology, Universidade Federal de Santa Catarina, Trindade campus, Florianópolis, Santa Catarina, BRAZIL. sofiazank@gmail.com

Natalia Hanazaki, Laboratory of Human Ecology and Ethnobotany, Department of Ecology and Zoology, Universidade Federal de Santa Catarina, Trindade campus, Florianópolis, Santa Catarina, BRAZIL.

Anderson Santos de Mello, Systematics Laboratory of Vascular Plants, Department of Botany, Federal University of Rio Grande do Sul, Porto Alegre, Rio Grande do Sul, BRAZIL.

Ethnobotany Research \& Applications 14:357-366 (2015)

\section{Published: 08 December 2015}


for conservation in the last decades, promoting the use of local knowledge in conservation actions (Albuquerque 2010, Hanazaki et al. 2010). Much of local participation in ethnobotanical studies is still dedicated to data collection and validation, rarely focusing on concerns with local demands such as empowering communities for resource management (Hanazaki et al. 2013). In order to collaborate with the process of community empowerment, it is necessary that the researcher begin to act more as a facilitator in participatory learning systems, letting go of the control in research development and allowing for the participation, action, and reflection from the communities studied (Geilfus 2008).

Among biodiversity recognized and managed by local populations, medicinal plants are highlighted for their species richness (Begossi et al. 2002, Chowdhury \& Koike 2010, Fonseca-Kruel \& Peixoto 2004) and for their importance in the maintenance of community health. Considering the value of these species as a therapeutic resource and a source of economic revenue, it is important to carry out investigations on local actions and reflections, aiming to conciliate the use and conservation of species to social development and well-being.

Protected areas (PA) of sustainable use allow for the conciliation of biodiversity conservation and the use of part of their resources. In this way, they become interesting places for the development of ethnobotanical studies employing participatory approaches. The Sustainable Development Reserve (SDR) of Areais da Ribanceira is a PA of sustainable use which has been proposed by the initiative of a local community of farmers and fishermen. This SDR aims to guarantee the territories of this traditional population and the use and conservation of important resources for their livelihoods, such as medicinal plants. The objective of this article is to bring reflection on the role of participatory approaches in ethnobotanical research aimed at in-situ conservation and local development, using the identification of conservation priority native medicinal plants in the SDR region (SDR Areais da Ribanceira proposed area) as an example, as well as identifying the main threats and opportunities to the conservation of such species.

\section{Study area}

The Areais da Ribanceira (28 $\left.12^{\prime \prime} 12^{\prime} \mathrm{S}, 48^{\circ} 40^{\prime \prime} 40^{\prime} \mathrm{W}\right)$ region is located in the Municipality of Imbituba, on the central-south coast of Santa Catarina State, Brazil, about 90 $\mathrm{km}$ south of its capital Florianópolis. The study area sits within the Atlantic Forest (Mata Atlântica) Biome (IBGE 2004) and is formed by crystalline base hills reaching up to $150 \mathrm{~m}$ altitude, sand dunes, sandy cords, associated depressions, marshlands, and lagoons. Vegetation is represented by the sub-montane dense rainforest (hillside forests) and edaphic formations of first occupation (restingas) (IBGE 2012). Plant communities are diversi- fied within restingas, exhibiting tree, shrub, and herbaceous associations over sandy soils, and aquatic vegetation on the margins of lagoons/lakes and marshlands. Moreover, a savannah-like formation occurs on dunes and sandy cords, locally known as butiazal, in which the small palm Butia catarinensis Noblick \& Lorenzi (beachbutiá) dominates in high-density, associated with shrub and herbaceous communities, with occurrence restricted to the northern coast of Rio Grande do Sul and southern coast of Santa Catarina.

Historically, about 40 farmers' families have been managing the area where the SDR has been proposed. The area has been used traditionally by farmers and fishermen as cultivation sites, mainly for manioc (Manihot esculenta Crantz) under a shifting agriculture system. In the 1970s, part of these lands was expropriated in order to build an industrial plant, which was active from 1979 to 1992. Although expropriated, land use did not change: families would still cultivate. However, in the year 2000, the area went to private ownership, which intensified conflicts of the maintenance of traditional practices in this area. In 2002, local farmers created the Imbituba Rural Community Association (ACORDI - acronym in Portuguese), with the main objective of regulating the use on their lands, granted proper acknowledgment as a traditional population. Since 2005 , the community has been pressing for their territory ownership through the proposal of the Sustainable Development Reserve Areais da Ribanceira (Zank et al. 2013), with an approximate area of 2100 hectares. From 2008 on, due to an ACORDI demand, research and extension projects have been developed in partnerships with the local community, aiming for the identification and register of traditional practices regarding land and resource use (Hanazaki et al. 2012).

\section{Methods}

\section{Data collection and analyses}

The research project was presented to the members of ACORDI, requesting their authorization for data collecting, which included individual interviews and participatory workshops. The leadership of the ACORDI signed an informed consent document, and the participation of each person was dependent on the acceptance of an individual term of prior informed consent.

This study included a survey about medicinal species known in the region using semi-structured interviews and free listings with 23 key informants (9 men and 14 women ranging from 40 to 86 years old), detailed in Zank \& Hanazaki (2012). Nine informants are member of ACOR$\mathrm{DI}$, and the others are recognized as medicinal plant specialists for the community of Areais da Ribanceira. Samples of the plants mentioned by the participants were collected following the standards for ethnobotany (Cunningham 2001) and identified using relevant resources (Loren- 


\section{Zank et al. - Participatory Approaches and Conservation of Medicinal Plants: Identifying priority species in the community of Areais da Ribanceira (Brazil)}

zi \& Matos 2008) and consultations with experts in botany. Voucher specimens were deposited at FLOR herbarium (Federal University of Santa Catarina, Brazil) or were registered in the collection of the Laboratory of Human Ecology and Ethnobotany (Federal University of Santa Catarina).

We considered the plants cited as spontaneous for at least one informant of this preliminary survey. For a spontaneous plant, we collected information about its origin (native or exotic to Brazil) and occurrence in different ecosystems of the restinga (Falkenberg 1999) and Atlantic Dense Rainforest (Flora do Brasil 2013, Lorenzi \& Matos 2008, Sehnem 1984), as well as whether these species occur in areas degraded by human actions (ruderal species) (Flora do Brasil 2013, Lorenzi \& Matos 2008). From the native medicinal plant listings, citation frequency and cultural saliency were calculated for each species according to the combination of citation frequency of the species and its citation order (Robbins \& Nolan 1997).

We carried out a participatory workshop with the Areais da Ribanceira community, for which all members of ACORDI were invited. Fifteen farmers (12 men and 3 women) were present in the workshop; eight of them were previously interviewed informants. We presented a list of species with citations superior to $20 \%$ and requested that farmers would select the 10 most important plants by consensus, in order to discuss their availability and environments where they could be found. Then, two participatory tools were applied: four-cell analysis and the environments and plants matrix (De Boef \& Thijssen 2007). In the four-cell analysis, species were analyzed according to the community's perception about environmental availability and harvest intensity for each species. This analysis allowed for the identification of the most common and most harvested plants by the community, as well as plants likely to be in a situation of risk due to their low environmental availability and high harvest rates. As for the environments and plants matrix, places of occurrence and harvest preferences were identified for medicinal plants.

\section{Results}

\section{Native medicinal plants and selection of priority plants for conservation}

From 91 named medicinal plants spontaneously listed (see Zank \& Hanazaki 2012), it was possible to identify 80 scientific species. Almost all species (95\%) cited as spontaneous by informants are native to Brazil. From these, $75 \%$ occur in restinga environments (pioneer formations) and $39 \%$ occur in hillsides (sub-montane dense rainforest). A considerable number $(28 \%)$ of species are ruderals, and one species, Ocotea odorifera (Vell.) Rohwer, is endangered (MMA 2008).

Native medicinal plants cited by at least $20 \%$ of key informants in Imbituba are presented in Table 1. Ten of these were selected by the community as most important ethno-

Table 1. Native medicinal plants cited by at least $20 \%$ of key informants in Imbituba $(n=23)$. In blue are ten ethno-species selected as most important for the community. Occurrence based on Sehnem (1984), Harley (1985), Falkenberg (1999), and consultation with specialists: RE = restinga environments, DR = dense rainforest, RU = ruderal plants. Voucher numbers: F = FLOR herbarium (Federal University of Santa Catarina); L = Collection of the Laboratory of Human Ecology and Ethnobotany (Federal University of Santa Catarina); IF = Identified in field; NI = Not identified. More than one scientific species is locally named quina, but it was only possible to confirm identification of $P$. crenata.

\begin{tabular}{|c|c|c|c|c|c|c|c|}
\hline \multicolumn{2}{|l|}{ Plant names } & \multicolumn{3}{|c|}{ Occurrence } & \multirow{2}{*}{ 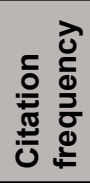 } & \multirow{2}{*}{ 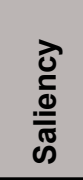 } & \multirow{2}{*}{ 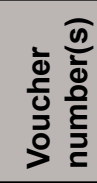 } \\
\hline Scientific [Family] & Vernacular & RE & DR & RU & & & \\
\hline Lepidium didymum L. [Brassicaceae] & menstruz & & & $x$ & 56.5 & 0.26 & L1198 \\
\hline Maytenus ilicifolia Mart. ex Reissek [Celastraceae] & \multirow{2}{*}{ espinheira-santa } & \multirow{2}{*}{$\mathrm{x}$} & \multirow{2}{*}{$\mathrm{x}$} & & \multirow{2}{*}{56.5} & \multirow{2}{*}{0.36} & L1155 \\
\hline Zollernia ilicifolia (Brongn.) Vogel [Fabaceae] & & & & & & & L1156 \\
\hline Aristolochia triangularis Cham. [Aristolochiaceae] & cipó-mil-homens & $x$ & $x$ & & 52.2 & 0.28 & L1143 \\
\hline Calea uniflora Less. [Asteraceae] & arnica & $\mathrm{x}$ & & & 47.8 & 0.27 & L1236 \\
\hline Bidens pilosa L. [Asteraceae] & picão & $\mathrm{x}$ & $x$ & $\mathrm{x}$ & 47.8 & 0.34 & L1209 \\
\hline Phyllanthus tenellus Roxb. [Phyllanthaceae] & quebra-pedra & $x$ & & $x$ & 43.5 & 0.25 & L1216 \\
\hline Dioscorea altissima Lam. [Dioscoreaceae] & salsa-parrilha & $x$ & & & 39.1 & 0.22 & L1223 \\
\hline Mikania laevigata Sch.Bip. ex Baker [Asteraceae] & guaco & $\mathrm{x}$ & $x$ & & 39.1 & 0.22 & L1237 \\
\hline Equisetum giganteum L. [Equisetaceae] & cavalinha & $x$ & & & 34.8 & 0.15 & L1136 \\
\hline Ocimum campechianum Mill. [Lamiaceae] & $\begin{array}{l}\text { anis, erva-doce, } \\
\text { são-simão }\end{array}$ & & & $x$ & 34.8 & 0.16 & L1148 \\
\hline
\end{tabular}




\begin{tabular}{|c|c|c|c|c|c|c|c|}
\hline \multicolumn{2}{|l|}{ Plant names } & \multicolumn{3}{|c|}{ Occurrence } & \multirow{2}{*}{ 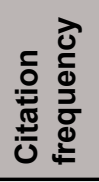 } & \multirow{2}{*}{$\begin{array}{l}\text { তे } \\
\frac{c}{0} \\
\frac{.}{\pi} \\
\text { ஸे }\end{array}$} & \multirow{2}{*}{ 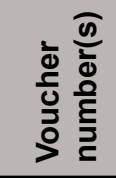 } \\
\hline Scientific [Family] & Vernacular & RE & DR & RU & & & \\
\hline $\begin{array}{l}\text { Alternanthera brasiliana (L.) Kuntze } \\
\text { [Amaranthaceae] }\end{array}$ & $\begin{array}{l}\text { meracilina, } \\
\text { penicilina }\end{array}$ & $x$ & & $x$ & 30.4 & 0.15 & L1199 \\
\hline Eugenia uniflora L. [Myrtaceae] & pitanga & $\mathrm{x}$ & $\mathrm{x}$ & & 30.4 & 0.21 & $\mathrm{~L} 1210$ \\
\hline Passiflora edulis Sims [Passifloraceae] & maracujá & $x$ & & & 30.4 & 0.18 & L1191 \\
\hline Achyrocline satureioides (Lam.) DC. [Asteraceae] & marcela-do-campo & $x$ & & & 26.1 & 0.16 & L1192 \\
\hline Baccharis crispa Spreng. [Asteraceae] & \multirow{2}{*}{ carqueja } & \multirow{2}{*}{$x$} & & & \multirow{2}{*}{26.1} & \multirow{2}{*}{0.16} & L1154 \\
\hline Baccharis milleflora (Less.) DC. [Asteraceae] & & & & & & & L1130 \\
\hline $\begin{array}{l}\text { Cuphea carthagenensis (Jacq.) J.F. Macbr. } \\
\text { [Lythraceae] }\end{array}$ & sete-sangria & $x$ & & & 26.1 & 0.16 & F38678 \\
\hline Psidium cattleianum Afzel. ex Sabine [Myrtaceae] & araçá & $x$ & $x$ & & 26.1 & 0.14 & IF \\
\hline Psidium guajava L. [Myrtaceae] & goiaba & & & $x$ & 26.1 & 0.11 & IF \\
\hline $\begin{array}{l}\text { Bauhinia microstachya (Raddi) J.F.Macbr. [Fa- } \\
\text { baceae] }\end{array}$ & pata-de-vaca & $x$ & & & 21.7 & 0.15 & L1206 \\
\hline Varronia curassavica Jacq.[Boraginaceae] & baleeira & $x$ & & & 21.7 & 0.12 & L1119 \\
\hline Lantana camara L. [Verbenaceae] & $\begin{array}{l}\text { bem-me-quer, } \\
\text { calêndola }\end{array}$ & $\mathrm{x}$ & $\mathrm{x}$ & $x$ & 21.7 & 0.13 & L1121 \\
\hline Ocotea odorifera (Vell.) Rohwer [Lauraceae] & canela-sassafraz & & $\mathrm{x}$ & & 21.7 & 0.13 & $\mathrm{NI}$ \\
\hline $\begin{array}{l}\text { Stachytarpheta cayennensis (Rich.) Vahl } \\
\text { [Verbenaceae] }\end{array}$ & $\begin{array}{l}\text { gervão, } \\
\text { gervão-roxo }\end{array}$ & $x$ & $x$ & $x$ & 21.7 & 0.13 & L1164 \\
\hline $\begin{array}{l}\text { Picrasma crenata Engl. in Engl. \& Prantl } \\
\text { [Simaroubaceae] }\end{array}$ & $\begin{array}{l}\text { quina, } \\
\text { quina-do-mato }\end{array}$ & $x$ & $x$ & & 21.7 & 0.13 & L1207 \\
\hline
\end{tabular}

species (in one case this includes two scientific species: Maytenus ilicifolia Mart. ex Reissek and Zollernia ilicifolia (Brongn.) Vogel). Most species selected by farmers are those with high values for frequency and saliency, with the exception of Achyrocline satureioides (Lam.) DC., Picrasma crenata Engl. in Engl. \& Prantl, and Stachytarpheta cayennensis (Rich.) Vahl.

\section{Community use and conservation of medicinal plants}

Three of the selected species are herbaceous, three are vines, two are shrubs, and two are trees. Four species have their leaves or twigs used (Equisetum giganteum L., Z. ilicifolia or M. ilicifolia, Lepidium didymum L., Mikania laevigata Sch.Bip. ex Baker), one species the flower ( $A$. satureioides), one the roots (Dioscorea altissima Lam.), one the stem (Aristolochia triangularis Cham.), and one the bark ( $P$. crenata). Two whole plant species were used (Calea uniflora Less. and S. cayennensis).

Four-cell analysis allowed for the exploration of the community's perception on environmental availability and harvest intensity for species studied. From the community's point-of-view, most species present a high environmental availability (Table 2), and only two species were considered poorly available. As for intensity of harvest, three species were considered at a low-extraction rate. Thus, most plants are intensely used and harvested by the local community, especially for domestic use, demonstrating the importance of such species to the maintenance of health and well-being. Equisetum giganteum was mentioned as occasionally commercially harvested, the same for Z. ilicifolia/M. ilicifolia and A. satureioides. Informants highlighted that careless extraction of $E$. giganteum and Z. ilicifolia/M. ilicifolia by people from outside of the community concerns farmers, since it could deplete this resource for the community. As discussed by a farmer of ACORDI during the individual interview: "They ended up with cavalinha (E. giganteum)! We cut in time, after it put seeded."

The most threatened species is $P$. crenata for it was considered as having limited environmental availability and intensely extracted. According to farmers, excessive bark extraction, which kills individual plants and contributes to 


\section{Zank et al. - Participatory Approaches and Conservation of Medicinal Plants: 361 Identifying priority species in the community of Areais da Ribanceira (Brazil)}

Table 2. Results of the four-cell analysis participatory tool on environmental availability and intensity of extraction of ten native medicinal ethno-species at Areais da Ribanceira.

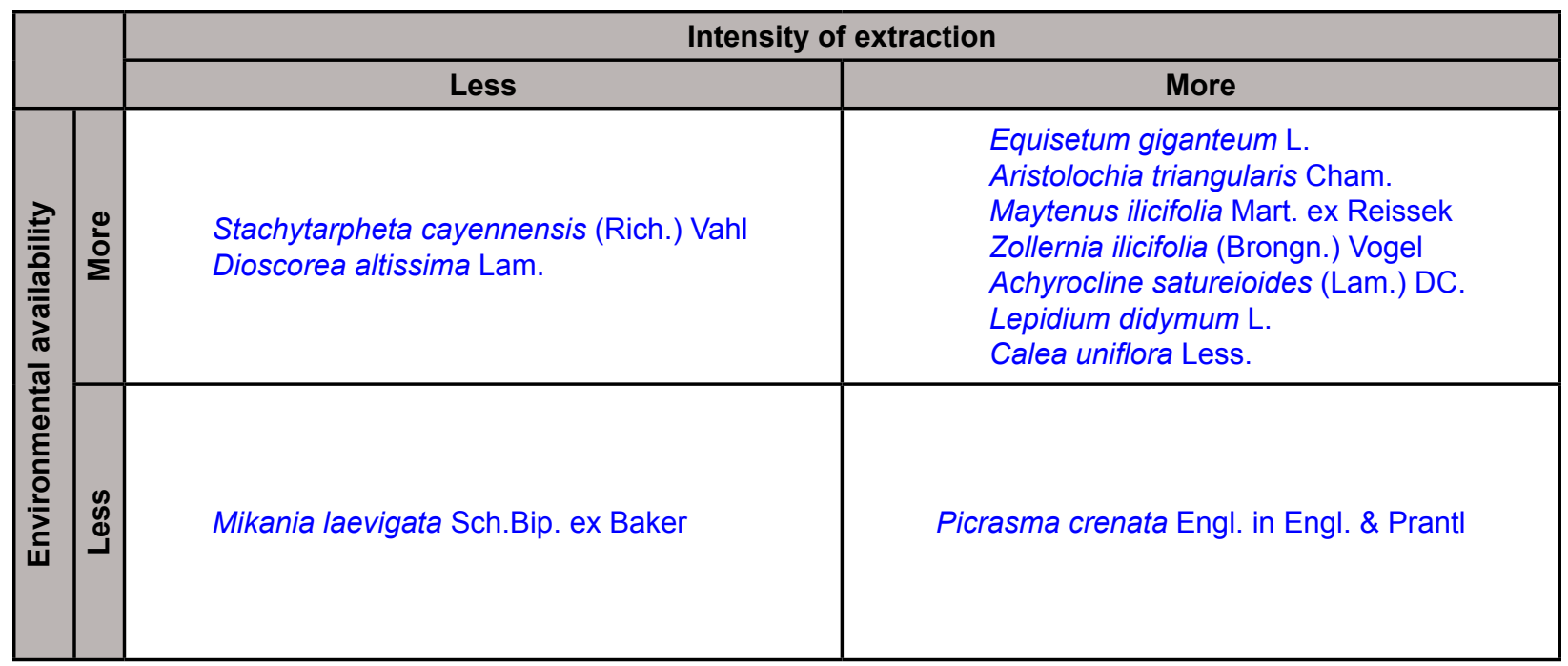

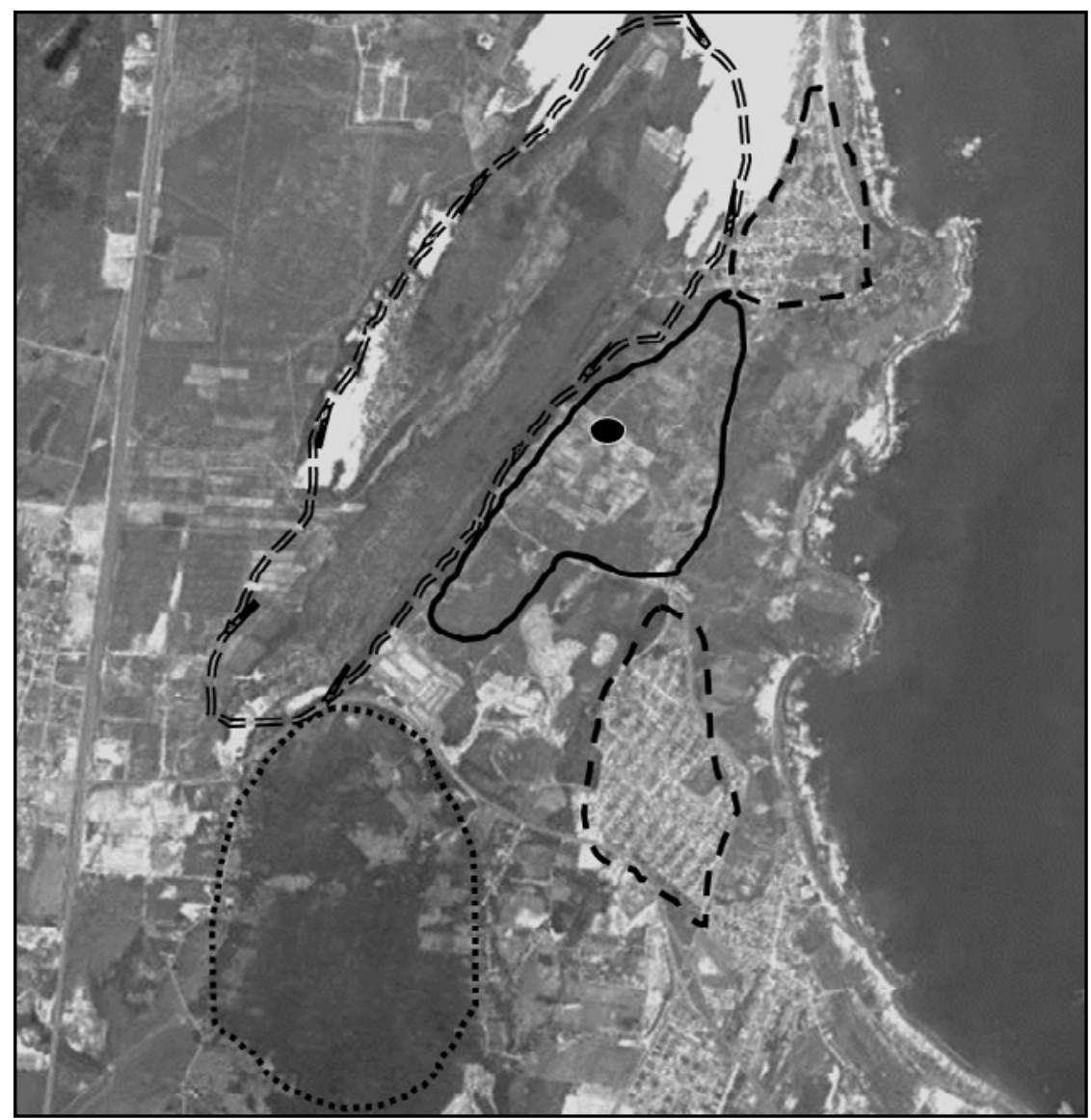

(I) Restinga woodland/

" " capoeira

$\cdots$ Hillside woodlands/

... capoeira

Mosaic of croplands, capoeiras, and butiazal

, House places - backyards

ACORDI association

Figure 1. Areais da Ribanceira Map (Brazil) depicting the mosaic of environments used by the community for the acquisition of medicinal plants. 
Table 3. Environment and plant matrix created during participatory workshop with the Areais da Ribanceira community, indicating environments where 10 native medicinal ethno-species occur and are harvested $(+)$ and environments with largest abundance and extraction for each species (++). Capoeira are secondary forests often derived from slashand-burn cultivation.

\begin{tabular}{|c|c|c|c|c|c|c|c|c|c|c|c|}
\hline & \multicolumn{11}{|c|}{ Scientific species (representing ethnospecies) } \\
\hline Environments & 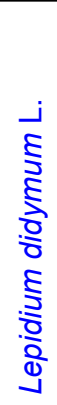 & 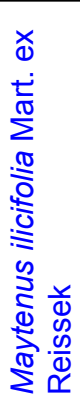 & 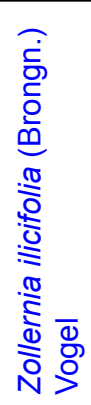 & 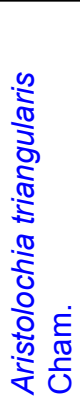 & 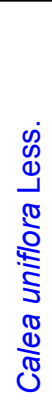 & 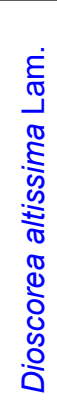 & 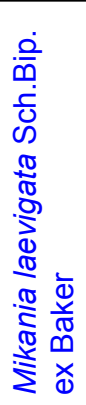 & 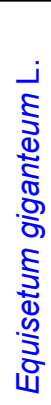 & 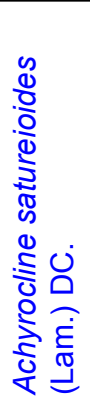 & 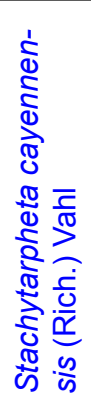 & 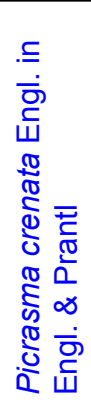 \\
\hline Marshlands & & & & & & & & ++ & & & \\
\hline Restinga woodland & & & & + & & ++ & + & & & & \\
\hline Hillside forest & & & & ++ & & & + & & & & ++ \\
\hline Capoeira* $^{*}$ & & & & & & & & & ++ & & \\
\hline Cropland & & & & & ++ & & & & ++ & ++ & \\
\hline Homegardens & ++ & & & & & & ++ & & & ++ & \\
\hline
\end{tabular}

deforestation of hillsides, is responsible for the decrease of this species' availability.

The environment and plant matrix served the community in identifying six environments where the 10 ethnospecies occur and are harvested: marshlands, restinga woodlands, hillside forests, cropland (slash-and-burn cropland), capoeira (secondary forests-often derived from slash-and-burn cultivation), and homegardens (Figure 1 and Table 3). Restinga and slope woodlands are environments where medicinal plants are most abundant. Fallow cultivated areas in restinga and capoeiras are also important for harvesting of plants such as $C$. uniflora, S. cayennensis, and $A$. satureioides.

Four out of ten species are cultivated in homegardens, confirming the importance of such environments for the acquisition of these native plants. Mikania laevigata is an example of a species largely harvested from homegardens, since it is less abundant in woodlands. Access to the most important medicinal plants assessed is facilitated, for harvest sites are mostly within disturbed areas.

Farmers identified two main threats to medicinal plants. The first was the alteration and suppression of restinga and hillside environments for housing and industrial buildings, as reported by a farmer: "Surrounded boqueirão, it is there that has many herbs; butua is just there." The second threat is that medicinal plants are harvested by outsiders, since the community does not have ownership nor control over the Areais area.

\section{Discussion}

Parameters such as frequency and saliency, based on free listings, are commonly used in order to select the most important species in ethnobotanical studies in which participatory strategies are not employed (Amusa et al. 2010, Gandolfo \& Hanazaki 2011, Houehanou et al. 2011). On the other hand, involving the community in selecting plants through more participatory approaches allowed the farmers to include species with low values under such parameters, but with a community importance, such as $A$. satureioides, $S$. cayennensis, and $P$. crenata. Achyrocline satureioides and $S$. cayennensis are abundant species in croplands and capoeiras, easily accessible by farmers. Picrasma crenata is a species widely recognized for its medicinal use, but it is increasingly hard for farmers to find.

The use of leaves or flowers does not imply threats to the subsistence of individual plants. However, for species in which roots $(D$. altissima), stem ( $A$. triangularis), and bark ( $P$. crenata) are used, the harvest can lead to individual plant death. Extraction, therefore, must be carefully evaluated. Of the two species that are used whole, C. uniflora has its distribution restricted to herbaceous restinga on the southern coast of Santa Catarina; thus, its extraction must be assessed with caution. On the other hand, S. cayennensis is a ruderal species, widely distributed in Brazil; therefore, extraction should not imply risk to the species.

Species' pharmacological properties are only supported for a handful of species. Calea uniflora works as a fungicide and anti-trypanosome (Budel et al. 2006). Mayte- 


\section{Zank et al. - Participatory Approaches and Conservation of Medicinal Plants: 363 Identifying priority species in the community of Areais da Ribanceira (Brazil)}

nus ilicifolia is anti-ulcerogenic and analgesic (Steenbock \& Reis 2011). Mikania laevigata is anti-ulcerogenic, anti-bacterial, a dental plaque removal agent, and anti-inflammatory (Dickel et al. 2011a). Achyrocline satureioides is antispasmodic, analgesic, anti-inflammatory, and a muscle relaxant (Dickel et al. 2011b, Lorenzi \& Matos 2008). Aristolochia triangularis must be administered with caution, since its genus is known for containing aristolochic acids that are carcinogenic (Di Stasi \& Hiruma-Lima 2002). The other species did not have their pharmacological properties investigated, but their uses are highly important for farmers.

The community prefers abundant and accessible plants occurring in disturbed areas near their homes. This was similarly demonstrated by other studies (Stepp \& Moerman 2001, Voeks 1996). These results highlight the importance for the maintenance of slash-and-burn agriculture environment mosaics (Siminski \& Fantini 2007), where croplands, capoeiras, and native vegetation can be found within the same space.

A four-cell analysis tool was effective for systematizing information about (1) the threats for diversity loss of harvested plants and (2) community considerations regarding possible reasons for losses and conservation of the medicinal species. The careless commercial extraction and deforestation of hillside areas were threats identified through this tool, and for the farmers the creation of the SDR would be one way to minimize these threats. Relevant application of this tool can also be seen for the identification of rare cultivated plant species and for the exploration for local conservation strategies for these species (De Castro et al. 2012, Rana et al. 2004). De Castro et al. (2012) used four-cell analysis to identify varieties of yams (Dioscorea spp.) that were cultivated by a few families and in small areas in the Amazon and thus are vulnerable to genetic erosion. In Nepal, after the use of this tool, Rana et al. (2004) identified the need for interventions for vulnerable species and varieties, such as the creation of collections of local varieties in the communities and income generation from these species/varieties, to ensure continuity of cultivation of them in productive units.

During the application of the tools, farmers demonstrated interest in commercializing some medicinal plants, creating a collective space for plant processing. They also recognized the importance of involving ecological studies on local management, to ensure sustainable use of this resource. The use of participatory tools for the selection of priority species was a first step toward the development of medicinal plant conservation in the region. It is important that population ecology studies on these plants are conducted (Reis et al. 1999). Such studies should involve researchers and local farmers, for the evaluation of species' distributions in different environments and harvest effects on population structures.
The community expressed interest to define and implement strategies for the conservation of their medicinal resources, but they are unsure how to initiate this process without having ownership of the territory. In 2010, due to an action of repossession, they lost part of their territory and their crops, and this situation is an on-going hindrance for conservation.

Farmers understand that the main action for conservation of such species is to guarantee their territory by establishing the Sustainable Development Reserve. Since harvesting of native species is done mainly on private areas (individual or communal areas not legally recognized as community's territory), access to medicinal plants has been gradually limited. The establishment of the proposed protected area can guarantee this community's territory, allowing for the maintenance of their traditional livelihoods in the Areais da Ribanceira region, which contributes directly to the mosaic of environments observed and serves as a source of medicinal plants. In addition to the farmers of ACORDI, the surrounding communities also have benefits from the creation of SDR, such as the maintenance of an area to provide ecosystem services that can be related to regional whole health and well-being (Zank et al. 2015).

Participatory processes also stimulate researchers' learning, as they become more flexible, through giving up control of research, being open to community demands, insights, local knowledge, and experiences. These allow for the community to guide research steps, strengthening community initiatives in decision-making regarding their resources. The researchers may act as a facilitators, sharing experiences and assisting people to achieve their maximum potential and identifying better solutions for local problems, a posture of a "new professionalism" (Geilfus 2008). This new professionalism in the field of ethnobotany is a valuable opportunity for promoting a more egalitarian connection between knowledge types, making research more engaged with social and environmental benefits.

Currently the community still struggles for the ownership of their territory as a way to regulate the extraction of plant resources and maintain small scale agriculture, activities that sustain their traditional livelihoods. Native medicinal plants remain as potential resources for future exploration, including use for commercial purposes. Furthermore, the application of this participatory tool based on data from the previous interviews reinforced the farmers' appropriation and valorization of their own knowledge.

Four-cell analysis is a simple tool-relatively quick and easily understandable - that allows more time to be dedicated to the discussion of the general scenario revealed collectively during a participatory workshop. The application of the participatory tool described here, together with other research efforts directed at the valorization of local 
knowledge and practices, are contributing to the gradual empowerment of the community (De Boef et al. 2013, Zank et al. 2013).

\section{Conclusions}

Native medicinal plants are used mainly as therapeutic resources for domestic use, with little commercial significance in the Areais da Ribanceira community. Among native plants most important to the community, the majority are recognized as highly available but under intense extraction pressure. However, among selected species, only $P$. crenata is considered under greater risk due to its limited environmental availability. Both natural areas (restinga, hillside forests) and cultivated areas (cropland, homegardens) are important for the acquisition of native medicinal plants.

A participatory focus generated results important for the local reality by involving the community in decision-making about the most important species and in the collective analysis of conservation aspects for such species (availability, extraction, environments of occurrence). This participatory process tends to facilitate the incorporation of research results in the community, according to its local demands, as well as allowing for a collective learning experience. Participants learned with one another and recognized the importance of their knowledge to decisionmaking regarding management and in-situ conservation of medicinal plant species.

\section{Acknowledgments}

We are grateful to the farmers of Rural Community Association of Imbituba for their openness in sharing their knowledge. Thanks to J.V. Avila, L. Sampaio, L. Cavechia, and M. Pinto for their help in data collection and D. Falkenberg, C. Simionatto, and M. Ritter for help in identifying plant specimens. N. Peroni, T. Castellani, R. Kubo, and $\mathrm{H}$. Liporacci provided insightful suggestions on a previous draft. We also thank CAPES, FAPESC, and CNPq for supporting this project (FAPESC financial support 7032/20107; CNPq financial support 478954/2009-3; N. Hanazaki scholarship 306895/2009-9).

\section{Literature Cited}

Albuquerque, U.P. 2010. Etnobotânica aplicada a conservação da biodiversidade. Pp. 351-364 in Métodos e Técnicas na Pesquisa Etnobotânica. Edited by U.P. Albuquerque, R.F.P. Lucena \& L.V.F.C. Cunha. NUPPEA, Recife, Brazil.

Alcorn, J. 1995. The scope and aims of ethnobiology in a developing world. Pp. 23-39 in Ethnobotany. Edited by R.E. Schultes \& S.V.Reis. Portland, Oregon, U.S.A.
Alexiades, M.N. 2003. Ethnobotany in the third millennium: Expectations and unresolved issues. Depinoa 45:15-28.

Amusa, T.O., S.O. Jimoh, P. Aridanzi \& M. Haruna. 2010. Ethnobotany and conservation of plant resources of Kainji Lake National Park, Nigeria. Ethnobotany Research and Applications 8:181-194.

Begossi, A., N. Hanazaki \& J.Y. Tamashiro. 2002. Medicinal plants and the Atlantic Forest (Brazil): Knowledge, use and conservation. Human Ecology 30(3):281- 299. doi:10.1023/A:1016564217719

Budel, J.M., M.R. Duarte, P.V. Farago \& I.J.M. Takeda. 2006. Caracteres anatômicos de folha e caule de Calea uniflora Less., Asteraceae. Revista Brasileira Farmacognosia 16(1):53-60. doi:10.1590/S0102$\underline{695 \times 2006000100010}$

Chambers, R. 1994. The origins and practice of participatory rural appraisal. World Development 22(7):953-969. doi:10.1016/0305-750X(94)90141-4

Chowdhury, M.S.H. \& M. Koike. 2010. Therapeutic use of plants by local communities in and around Rema-Kalenga Wildlife Sanctuary: Implications for protected area management in Bangladesh. Agroforest Systems 80:241257. doi:10.1007/s10457-010-9316-9

Cunningham, A.B. 2001. Applied Ethnobotany: People, wild plant use and conservation. Earthscan, London, U.K.

De Boef, W.S. \& M.H. Thijssen. 2007. Participatory Tools Working with Crops, Varieties and Seeds. A guide for professionals applying participatory approaches in agrobiodiversity management, crop improvement and seed sector development. Wageningen International, Wageningen, Netherlands.

De Boef, W.S., A. Subedi, N. Peroni, M. Thijssen \& E. O'Keefee. 2013. Community Biodiversity Management. Centre for Development Innovation, Wageningen, Netherlands.

De Castro, A.P., T.J.P. Fraxe \& H.S. Pereira. 2012. Etnobotânica das variedades locais do cará (Dioscorea spp.) cultivados em comunidades no município de Caapiranga, estado do Amazonas. Acta Botanica Brasilica 26(3):658667. doi:10.1590/S0102-33062012000300015

Di Stasi, L.C. \& C.A. Hiruma-Lima. 2002. Plantas Medicinais da Amazônia e na Mata Atlântica. Universidade Estadual Paulista "Júlio de Mesquita Filho," São Paulo, Brazil.

Dickel, M.L, M.R. Ritter \& I.B.I. De Barros. 2011a. Mikania laevigata. Pp. 652-655 in Espécies Nativas da Flora Brasileira de Valor Econômico Atual ou Potencial. Edited 


\section{Zank et al. - Participatory Approaches and Conservation of Medicinal Plants: 365 Identifying priority species in the community of Areais da Ribanceira (Brazil)}

by L. Coradin, A. Siminski \& A. Reis. Ministério do Meio Ambiente, Brasília, Brazil.

Dickel, M.L, M.R.Ritter \& I.B.I. De Barros. 2011b. Achyrocline satureoides. Pp. 541-544 in Espécies Nativas da Flora Brasileira de Valor Econômico Atual ou Potencial. Edited by L. Coradin, A. Siminski \& A. Reis. Ministério do Meio Ambiente, Brasília, Brazil.

Eyben, R., N. Kabeer \& A. Cornwall. 2008. Conceptualising Empowerment and the Implications for Pro Poor Growth: A paper for the DAC Poverty Network. Institute of Development Studies, Brighton, U.K.

Falkenberg, D.B. 1999. Aspectos da flora e da vegetação secundária da restinga de Santa Catarina, sul do Brasil. Insula 28:1-30.

Flora do Brasil. 2014. Lista de Espécies da Flora do Brasil. Jardim Botânico do Rio de Janeiro, Brazil. http://floradobrasil.jbrj.gov.br. Accessed 30 August 2014.

Fonseca-Kruel, V.S. \& A.L. Peixoto. 2004. Etnobotânica na Reserva Extrativista Marinha de Arraial do Cabo, RJ, Brasil. Acta Botanica Brasílica 18(1):177-190. doi:10.1590/ $\underline{\text { s0102-33062004000100015 }}$

Gandolfo, E.S. \& N. Hanazaki. 2011. Ethnobotany and urbanization: Knowledge and use of restinga plants by the native community of Distrito do Campeche (Florianópolis, Santa Catarina, Brazil). Acta Botanica Brasilica 25(1):168-177.

Gaventa, J. \&A. Cornwall. 2006. Challenging the boundaries of the possible: Participation, knowledge and power. IDS Bulletin 37(6):122-128. doi:10.1111/j.1759-5436.2006. tb00329.x

Geilfus, F. 2008. 80 Tools for Participatory Development: Appraisal, planning, follow-up and evaluation. Edited by B.M. Abaunza. Inter-American Institute for Cooperation on Agriculture, San Jose, Costa Rica. http://repiica.iica. int/docs/B1013I/B1013l.pdf

Hanazaki, N., E.S. Gandolfo, M. Bender, M. Giraldi, E.A. Moura, G. Coelho-de-Souza, R.B. Printes, M. Denardi \& R.R Kubo. 2010. Conservação biológica e valorização sócio-cultural: Explorando conexões entre a biodiversidade e a sociodiversidade. Pp. 89-102 in Etnoecologia em Perspectiva: Natureza, cultura e conservação. Organized by A.G.C. Alves, F.J.B. Souto \& N. Peroni. NUPEEA, Recife, Brazil.

Hanazaki, N., E.M. Nakamura, B. Lindner \& W.S. De Boef. 2013. Opportunities for ethonobotany to contribute to community biodiversity management. Pp. 141-144 in Community Biodiversity Management. Edited by W.S. De Boef, A. Subedi, N. Peroni, M. Thijssen \& E. O'Keefee.
Centre for Development Innovation, Wageningen, Netherlands.

Hanazaki, N., S. Zank, M.C. Pinto, L. Kumagai, L.A. Cavechia \& N. Peroni. 2012. Etnobotânica nos areais da Ribanceira de Imbituba: Compreendendo a biodiversidade vegetal manejada para subsidiar a Criação de uma Reserva de Desenvolvimento Sustentável. Biodiversidade Brasileira 2:50-64.

Houehanou, T.D., A.E. Assogbadjo, R.G. Kakai, M. Houinato \& B. Sinsin. 2011. Valuation of local preferred uses and traditional ecological knowledge in relation to three multipurpose tree species in Benin (West Africa). Forest Policy and Economics 13(7):554-562. doi:10.1016/j.forpol.2011.05.013

IBGE. 2004. Mapa de Biomas do Brasil. Instituto Brasileiro de Geografia e Estatística, Rio de Janeiro, Brazil. www. ibge.gov.br/home/geociencias/recursosnaturais/mapas/ mapasdoc1.shtm Accessed 30 August 2014.

IBGE. 2012. Manual técnico da vegetação brasileira. In Manuais Técnicos em Geociências 1. Instituto Brasileiro de Geografia e Estatística, Rio de Janeiro, Brazil.

Lorenzi, H. \& F.J.A. Matos. 2008. Plantas Medicinais no Brasil - Nativas e exóticas. Second edition. Nova Odessa, São Paulo, Brazil.

MMA. 2008. Lista Oficial das Espécies da Flora Brasileira Ameaçadas de Extinção. Ministério do Meio Ambiente, Brasília, Brazil. www.mma.gov.br/estruturas/ascom boletins/ arquivos/83 19092008034949.pdf Accessed 22 July 2015.

Rana, R.B., B.R. Sthapit \& C. Garforth. 2004. Four-cells analysis as a decision-making tool for conservation of agrobiodiversity on-farm. Pp. 15-25 in On-farm Conservation of Agricultural Biodiversity in Nepal. Edited by B.R. Sthapit, M.P. Upadhyay, P.K. Shrestha \& D.I. Jarvis. Nagarkot, Nepal.

Reis, M.S., A. Mariot \& L.C. Di Stasi. 1999. Manejo de populações naturais de plantas medicinais na Floresta Atlântica. Pp. 95-102 in Comunidades Tradicionais e Manejo dos Recursos da Mata Atlântica. Organized by A.C. Diegues \& V.M. Viana. Hucitec, NUPAUB-USP, São Paulo, Brazil.

Robbins, M.C. \& J.M. Nolan. 1997. A measure of dichotomous category bias in free-listing tasks. Cultural Anthropology Methods Journal 9(3):8-12. doi:10.1177/152582 2x970090030501

Sehnem, A. 1984. Equisetáceas. In Flora Ilustrada Catarinense. Edited by P.R. Reitz. Itajaí, Brazil. 
Sieber, S.S, C.S. Taline, L.Z.O. Campos, S. Zank \& U.P. Albuquerque. 2014. Participatory methods in ethnobiological and ethnoecological research. Pp. 39-58 in Methods and Techniques in Ethnobiology and Ethnoecology. Edited by U.P. Albuquerque, R.F.P. Lucena, L.V.F.C. Cunha \& R.R.N. Alves. Springer, São Paulo, Brazil. doi:10.1007/978-1-4614-8636-7 3

Siminski, A. \& A.C. Fantini. 2007. Roça-de-toco: Uso de recursos florestais e dinâmica da paisagem rural no litoral de Santa Catarina. Ciência Rural 37(3):690-696. doi:10.1590/S0103-84782007000300014

Steenbock, W. \& M.S. Reis. 2011. Maytenus ilicifolia. Pp. 636-648 in Espécies Nativas da Flora Brasileira de Valor Econômico Atual ou Potencial. Edited by L. Coradin, A. Siminski \& A. Reis. Ministério do Meio Ambiente, Brasília, Brazil.

Stepp, J.R. \& D.E. Moerman. 2001. The importance of weeds in ethnopharmacology. Journal of Ethnopharmacology 75:19-23. doi:10.1016/S0378-8741(00)00385-8
Voeks, R.A. 1996. Tropical forest healers and habitat preference. Economic Botany 50(3):354-373. doi:10.1007/ $\underline{\text { bf02866520 }}$

Zank, S., A.L. Assis, M. Borges, N. Peroni \& N. Hanazaki. 2013. The sustainable development reserve: An option for securing livelihoods in Imbituba, Brazil. Pp.169-174 in Community Biodiversity Management. Edited by W.S. De Boef, A. Subedi, N. Peroni, M. Thijssen \& E. O'Keefee. Centre for Development Innovation, Wageningen, Netherlands.

Zank, S. \& N. Hanazaki. 2012. Exploring the links between ethnobotany, local therapeutic practices, and protected areas in Santa Catarina coastline, Brazil. Evidence-based Complementary and Alternative Medicine 2012(563570):1-15. doi:10.1155/2012/563570.

Zank, S., N. Peroni, E.L. Araújo \& N. Hanazaki. 2015. Local health practices and the knowledge of medicinal plants in a Brazilian semi-arid region: Environmental benefits to human health. Journal of Ethnobiology and Ethnomedicine 11:11. doi:10.1186/1746-4269-11-11 